\title{
Quantitative vs. qualitative - do different research methods give us consistent information about our users and their library space needs?
}

\author{
Susan E. Montgomery
}

\begin{abstract}
Assessment of how library patrons use space and the evaluation of their needs has become a "hot" topic in library research. But determining the best way to obtain information about their activity can be a challenge. Two types of data collection are quantitative and qualitative. Quantitative data provides a numerical count of what activities students perform within the library and therefore can be measured. Qualitative data gives personal opinions, feedback and individual perspectives regarding a topic but is not measurable. In this study, we were interested to learn if we would get substantially different results from a user observation study, a quantitative method, than from the results of asking users about their library space needs, a qualitative method. Essentially, would the results from both methods provide complementary results enabling us to obtain a comprehensive picture about our patrons' needs and redesign the space to improve their library experience?

\section{Introduction}

At the Olin Library, we have begun investigating what our users do in the library. In an effort not to rely on anecdotal evidence and assumptions, we decided to employ two data collection techniques: observation, an ethnographic technique for gathering quantitative data, and a "charette," a traditional architectural design method which analyzes space and is utilized to obtain qualitative information. With the combination of both, we could learn if the data from these studies complemented or refuted each other. Our study sought to determine if we obtain substantially different results by observing users' behavior and asking about their library space needs. The findings would guide us to redesign the space and improve our student's experience in the library.
\end{abstract}

\section{Author}

Susan E. Montgomery is a Public Services Librarian at Olin Library, Rollins College in Winter Park, FL. Her research interests include "user's experience" and the "library as the third place."

Email: smontgomery@rollins.edu 
Ethnography relies on observing people in their natural settings or directly interacting with them in order to better understand their lives (Buchanan, 2000). Ethnographic techniques such as observations, photo surveys, interviews, or mapping diaries help libraries learn more about their users and how they use the library. That information assists libraries to make changes that complement our users' needs rather than what librarians THINK they need. Bryant (2009) explains that using ethnography can help librarians "explore what users are actually doing in their library." LaFlamme (2007) points out different users have different needs that "grow out of the material conditions and cultural contexts in which they live their lives."

In 1964, noted sociologist Pierre Bourdieu conducted a study of student use at the Lille University Library. There, Bourdieu first conducted a user behavior observation which he then followed with a questionnaire. The questionnaire, distributed as users entered the library, asked them about that particular visit to the library and their use of library space. The combination of both methods allowed Bourdieu to "link up various attitudes with the social characteristics of the individuals" (Bourdieu, 1965/1994).

The University of Rochester conducted an extensive two year study (2004-2006) of its students using multiple ethnographic methods. Their findings revealed "how the library intersects with students' complicated lives" (Briden, 2007). Rochester librarians discovered that users had diverse experiences with the library and its offerings. That diversity in library experience influenced what students expect from the library space.

In 2004, Sewanee University conducted a two year study of its library. The library task force dedicated themselves to developing a library strategic plan using the information they learned from the study. The research focused on the "learners and their needs" (Library Planning Task Force, 2005). The task force utilized student surveys, solicited senior essays about their intellectual experience at the university, as well as conducted student interviews and observations (Library Planning Task Force, 2005). The group learned about the student culture at the university and the role of the library.

Librarians at Wesleyan University Library in Middletown, CT conducted an ethnographic study of its students in preparation to renovate its Science Library. Previous renovations at the university did not include student input during the design process (Hobbs and Klare, 2010). With this opportunity, Wesleyan librarians were eager to learn more about their students by applying ethnographic techniques early in the process. The information gathered from their data collection would enable them to create a space that would be useful to their students.

The University of Massachusetts-Amherst held focus groups, observations and surveys prior to and after the construction of their Learning Commons. Librarians began collecting data in 2001, the year prior to the construction of Learning Commons, and continued gathering data after 2005 when the Learning Commons opened (University of Massachusetts, 2010). The qualitative data guided their quantitative research. The highly detailed information collected gave the 
librarians a comprehensive picture of how their patrons utilize the space to help them make changes in accordance with their users' needs.

Librarians utilize a variety of techniques in order to obtain quantitative or qualitative data to better understand their users and their space. In the studies mentioned previously, researchers often use a mixed methodology to gather information. The quantitative study usually informs the qualitative one. From the information gathered, librarians view trends and develop common themes that reveal the space needs of their users. In addition to contributing to ethnographic research literature conducted at other academic libraries, our research at Olin revealed that data from both studies gave us consistent information. Thus, this research has been a starting point in the ongoing learning about the users and space at our library.

\section{Background}

Olin, built in 1985, is the only library building on campus. Our student population of 3,005 Full-time equivalent (FTE) is comprised of a traditional undergraduate student body as well as an evening/weekend undergraduate program, a small graduate program and graduate business school. The library building is four floors and encompasses about 54,000 square feet. The main floor of the library is a high-traffic area with four computer labs, a reference area, the circulation desk, a meeting room, offices, and a popular café. It offers a variety of space for users including group tables, couches, big "comfy" chairs, study carrels and individual seating. The main floor also has an area that is open 24 hours during the academic year. Because of the variety of spaces and the high activity, we focused our research on the library's main floor. During the week of observations, the library's hours were 7:30 am to 12:00 am.

In November 2010, three librarians and one staff member participated in a two day College and Library Information Resources (CLIR) workshop for the Council of Independent Colleges (CIC) held at Rollins. Under the direction of Nancy Fried Foster, Director of Anthropological Research at the River Campus Libraries of the University of Rochester, the workshop provided training in a variety of ethnographic methods such as mapping diaries, photo journals, observation maps, interviewing, as well as conducting library design workshops.

\section{Method}

Following the CLIR workshop, Olin participants were eager to learn about our users employing ethnographic methods and decided to conduct two studies. In the "Activity Study," we observed the activity of our main floor during a typical week in the semester. In the second study, "Design Brainstorm Sessions," we invited students to participate in library design workshops for the same space. With both studies, we hoped to learn how students use the library space and what changes they would like to see. Each study provided different types of data; we wanted to learn if the results differed.

A team of four library employees: two librarians, two staff, modified the observation study from the University of Rochester to complete the "Activity Study." Observation provides researchers with the opportunity to "discover and 
validate behavioral patterns" (Mariampolski, 2006). The observations provided data on what activities students did while in the library. In our approach, we used an observation table to count what activities occurred on the main floor of the library. The team decided to observe our users on the floor from Sunday Thursday at 2:00 pm, 6:00 pm and 10:00 pm. In the end, we would have a total of 15 observations which would provide raw data about where people are and what they do in the library.

The lead librarian created two detailed maps of the 2nd floor of the library. Each map comprised half of the library floor and included stacks, study carrels, computer locations and various seating.

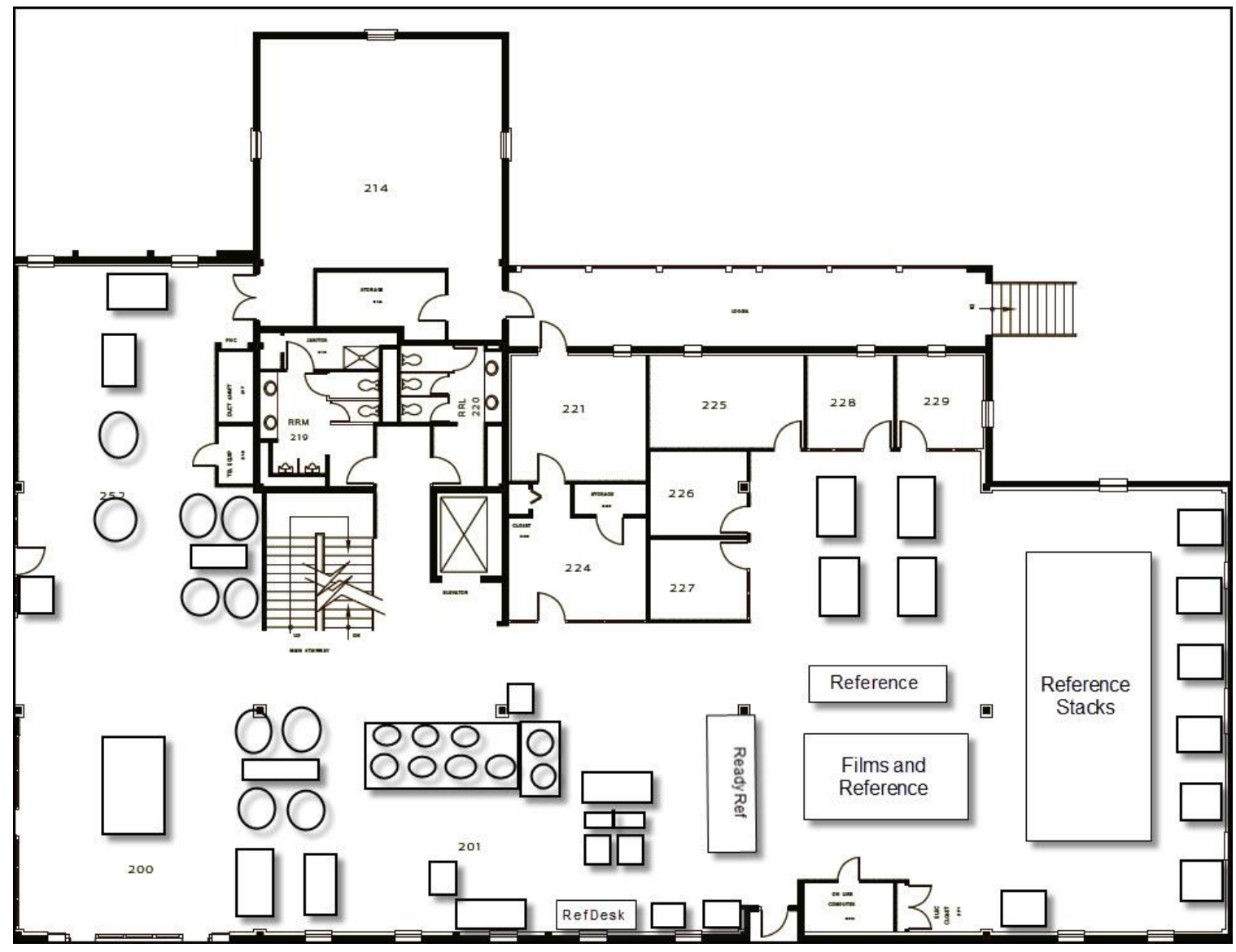

Figure 1: Olin Library main floor map used for observations 


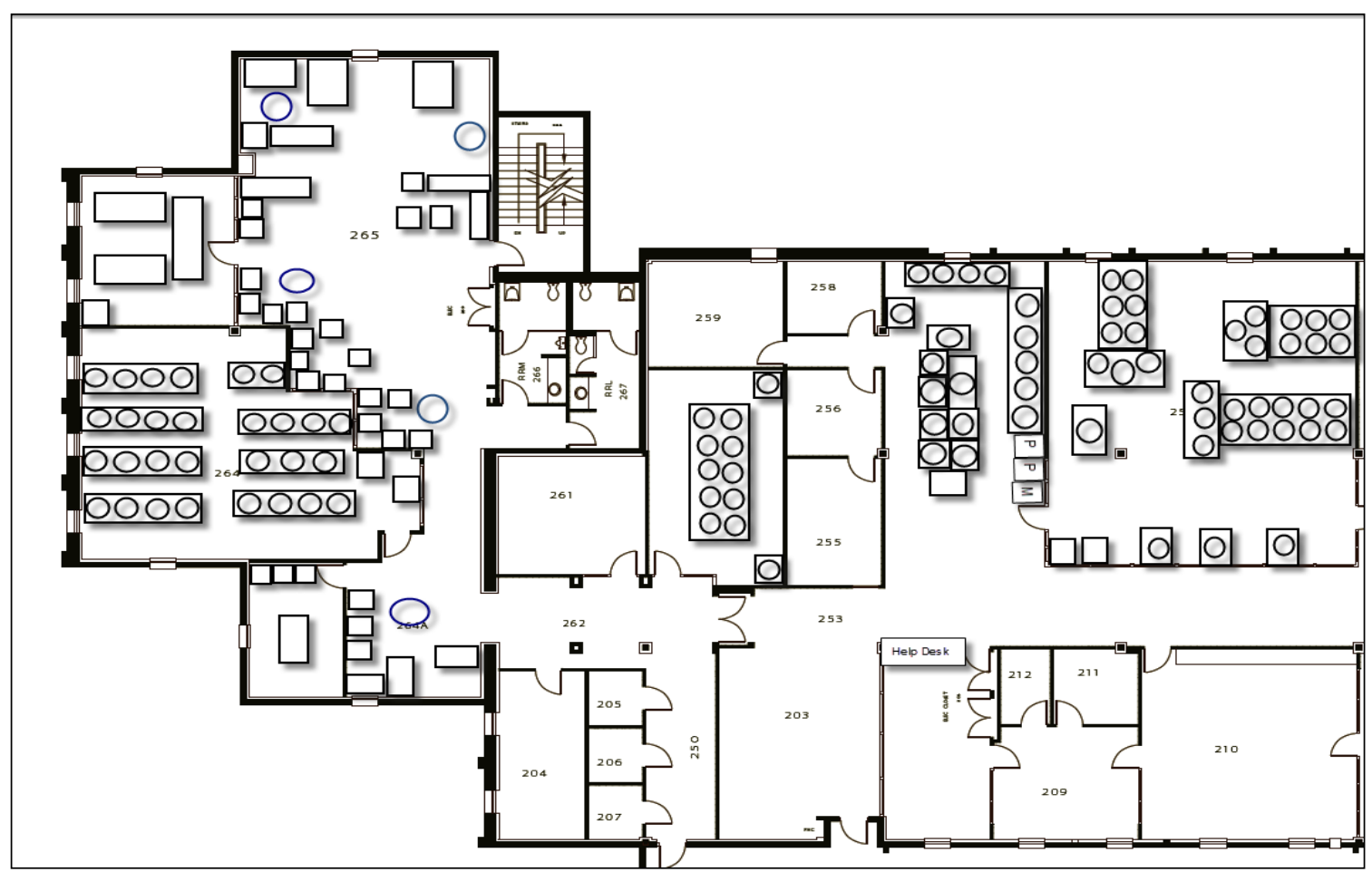

Figure 2: Olin Library main floor map used for observations 
An observation chart, based on the template provided by Nancy Fried Foster, accompanied each map.

\section{Observation Chart}

First, count the people on the $2^{\text {rt }}$ floor of the library. Use the floor plan to mark your observations, as follows: $A=$ person doing academic work

$\mathrm{R}=$ person doing "recreation" (Facebook, YouTube, email, chatting, eating)

$X=$ person sleeping, walking through area, or otherwise unengaged

$\mathrm{C}=$ person using a cellphone (talking, texting, etc.)

$L=$ person using a laptop (not plugged in)

$\mathrm{LP}=$ person using a laptop (pluggedin)

Note: draw ring around people who are doing ocodemic work with each other (in a pair or group) When you are done, count up the marks on yourfloor plan and note them in the top part of the chart, below. Next, spend five minutes observing in your designated area. Use the bottom part of the chart to make notes.

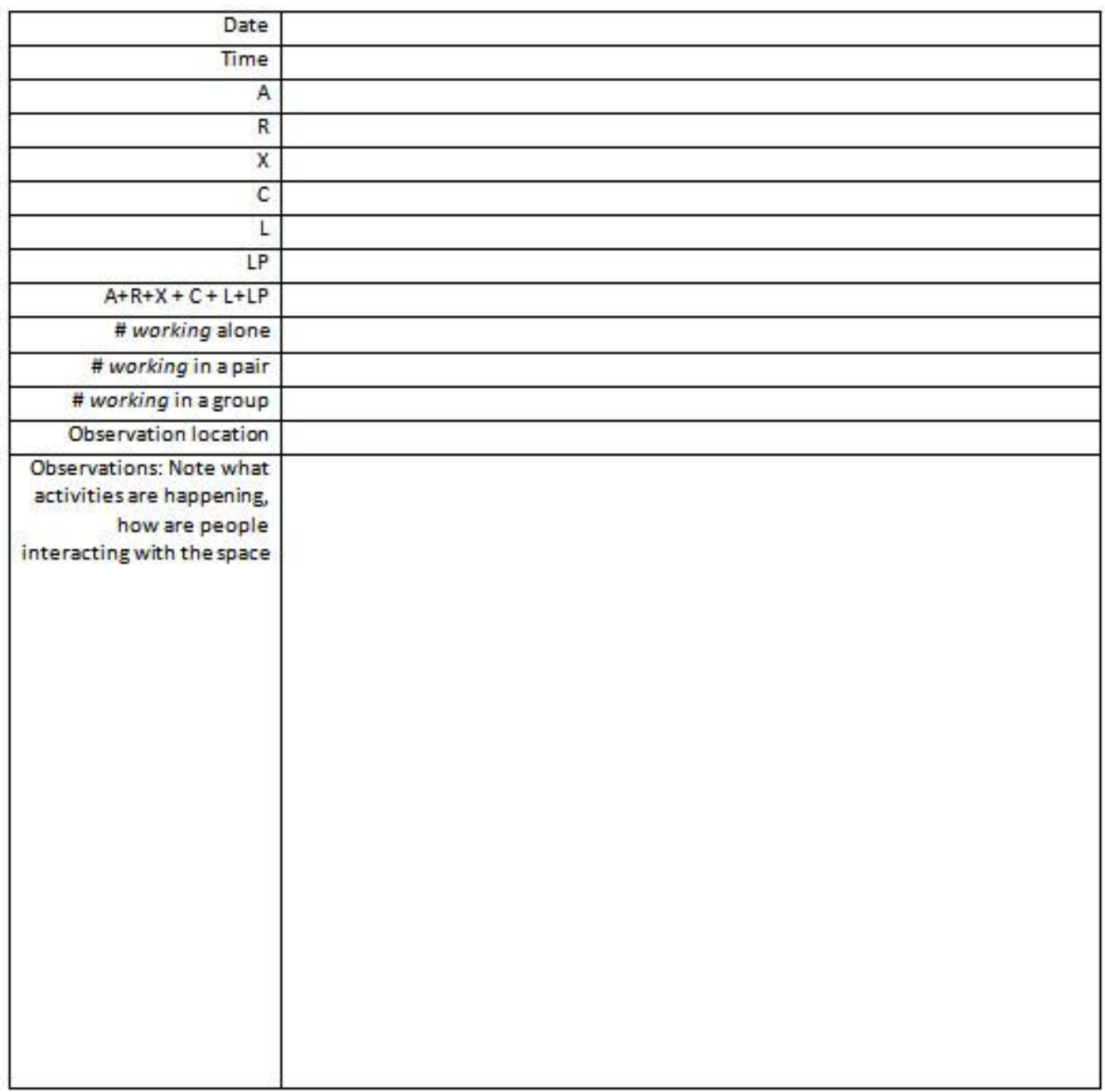

\section{Figure 3: Observation chart to count activity on Olin Library main floor}

We wanted to learn about the activities of our users: academic, recreational, unengaged, i.e. walking, sleeping, etc. Our study also included cellphone activity, battery operated laptop activity, and laptop activity when the computer was 
plugged into an outlet. The chart also included space to indicate students working in pairs and groups. The labeling options were:

A: Academic - reading academic material, writing,

R: Recreational - Facebook, Youtube, email, chatting,

$\mathrm{X}$ : Unengaged activity - sleeping, walking through, etc.

C: Cellphone activity

L: Using a laptop

LP: Using a laptop plugged in

The "Design Brainstorm Sessions" involved student discussion groups to learn how students use the main floor of the library and what changes they would make. These were inspired by the library design "charette" workshop conducted at the University of Rochester (Foster and Gibbons, 2007). A charette, traditionally an architecture exercise, is a design process where students are presented with "a design problem which they are to solve within an allotted time" (Aurand, 2011). The lead librarian sent emails inviting students to participate. Participants included students from our traditional student population, our evening and weekend program, and our business school. The lead librarian also walked around the dining hall at lunch to recruit students for the workshop. As in the Rochester study, we marketed the workshop to students with the phrase: " $\$ 5$ and food for 20 minutes of your time" (Foster and Gibbons, 2007). Our goal was to recruit a total of 20 students with representation from each of the different student populations. We had two different days for the workshops with the promise of pizza, soda and dessert. We succeeded in meeting our goal of student recruitment.

Unfortunately, we had a low participation level. Only half of the participants actually attended the workshops for a total of 10 participants, five each night. We recruited students a week in advance of the event not fully realizing that students "live in the present" and a week was too much notice. We were also more concerned about reaching a specific number which hampered our recruitment efforts. Future recruitment strategies will incorporate a shorter and more intense recruitment period utilizing multiple methods including our Facebook page, the library website, and possibly asking professors to identify students to participate or announce the event to their class. We realized our focus should be more on promoting the activity to a wide audience rather than reaching a specific number. In addition, we plan to offer a more attractive dining menu which may draw more students to participate. Fortunately, we did recruit a diverse group of students: 5 full-time students, 2 part-time students, and 3 MBA graduate students.

For the sessions, we conducted a blank map activity with the students. They were provided a blank map of the 2 nd floor of the library and given 10 minutes to design their ideal library space taking into account how they use the library and what changes they would like to see. 


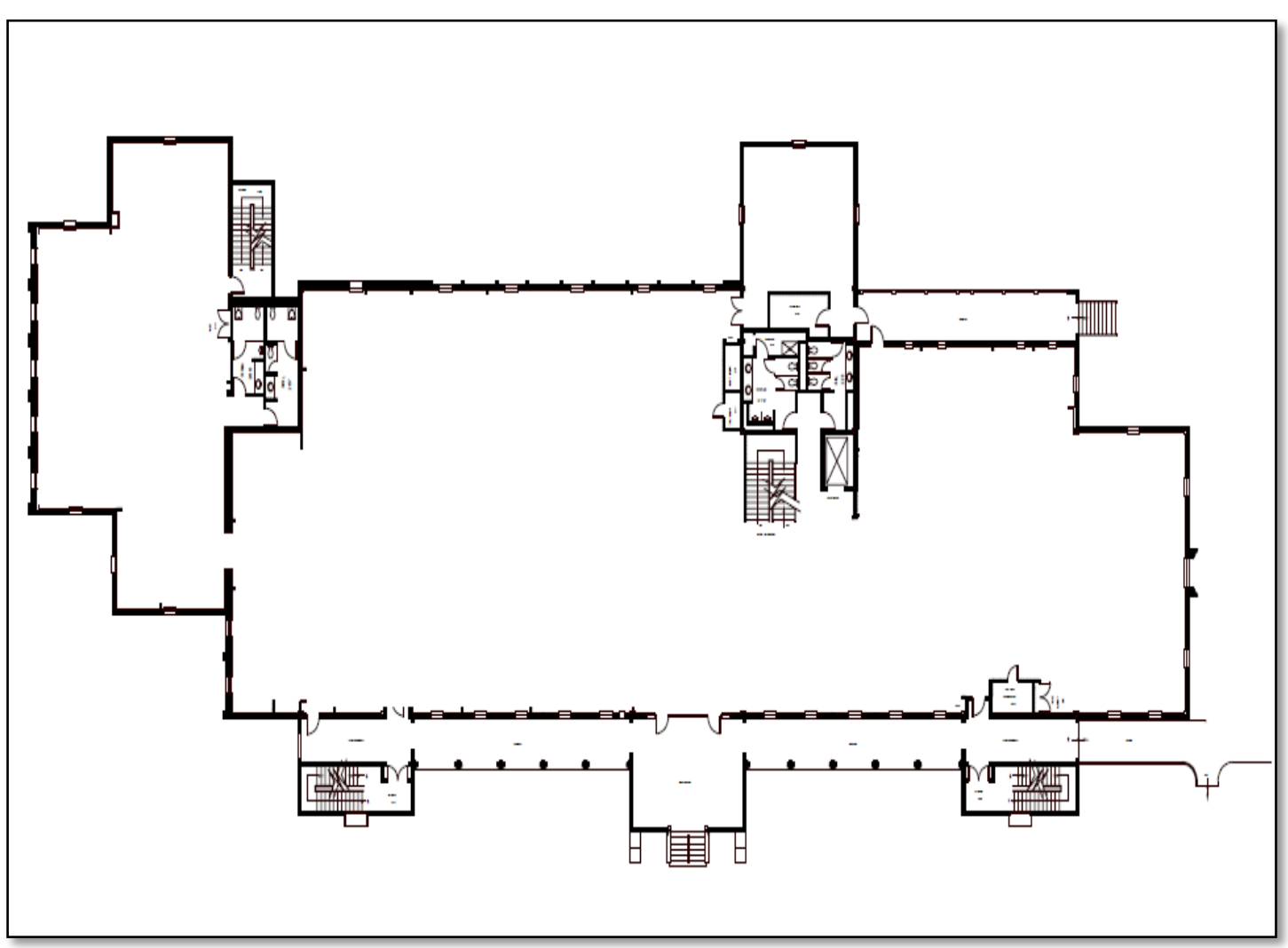

\section{Figure 4: Blank floor map of Olin Library main floor}

Students were encouraged to design the space without regard to cost. Designs had to be within the current footprint of the library, i.e. the square footage could not be increased, and the elevator, bathrooms and stairway could not be moved. After 10 minutes, we discussed the designs, highlighting features of the library they would maintain and changes they would like to see. After our discussion, we provided a second blank map to the students and based on the conversations, students designed the space again. We videotaped the sessions and had a staff member present to take notes.

\section{Findings}

The main floor of Olin Library is an open conversation area with group meeting tables as well as individual study carrels. The "Activity Study" provided quantitative data giving us a count of the activities people were doing on the main floor of the library at specific time periods. We collected a total of 15 observation reports which we organized into a table (Table 1). 


\begin{tabular}{|c|c|c|c|c|c|c|c|c|c|c|c|c|c|c|c|}
\hline $\begin{array}{l}\text { Observation } \\
\text { day \& time }\end{array}$ & $\begin{array}{l}\text { Academic } \\
\text { activity }\end{array}$ & $\begin{array}{c}\% \\
\text { academic } \\
\text { (daily) }\end{array}$ & $\begin{array}{c}\text { Recreation } \\
\text { activity }\end{array}$ & $\begin{array}{c}\% \\
\text { recreation } \\
\text { (daily) }\end{array}$ & $\begin{array}{l}\text { Cellphone } \\
\text { activity }\end{array}$ & $\begin{array}{c}\text { Unengaged } \\
\text { activity }\end{array}$ & $\begin{array}{c}\text { Activity on } \\
\text { laptops }\end{array}$ & $\begin{array}{c}\text { Activity on } \\
\text { laptops } \\
\text { (plugged in) }\end{array}$ & $\begin{array}{c}\text { Laptop } \\
\text { activity \% } \\
\text { (daily) }\end{array}$ & $\begin{array}{c}\text { Activity } \\
\text { alone }\end{array}$ & $\begin{array}{c}\% \\
\text { alone }\end{array}$ & $\begin{array}{l}\text { Activity } \\
\text { in pairs }\end{array}$ & \begin{tabular}{|c|} 
Activity \\
in groups
\end{tabular} & $\begin{array}{c}\% \text { in pairs } \\
\text { or groups } \\
\text { (daily) }\end{array}$ & $\begin{array}{c}\text { 2nd floor } \\
\text { total }\end{array}$ \\
\hline $\begin{array}{l}\text { Sunday, } \\
\text { 2:00 PM }\end{array}$ & 45 & $83 \%$ & 7 & $13 \%$ & 1 & 1 & 15 & 10 & $46 \%$ & 27 & $50 \%$ & 6 & 12 & $33 \%$ & 54 \\
\hline $\begin{array}{l}\text { Sunday, } \\
\text { 6:00 PM }\end{array}$ & 40 & $85 \%$ & 4 & $9 \%$ & 2 & 1 & 18 & 1 & $40 \%$ & 12 & $26 \%$ & 8 & 13 & $45 \%$ & 47 \\
\hline $\begin{array}{l}\text { Sunday, } \\
10: 00 \mathrm{PM}\end{array}$ & 38 & $62 \%$ & 18 & $30 \%$ & 1 & 4 & 17 & 9 & $43 \%$ & 20 & $33 \%$ & 6 & 12 & $30 \%$ & 61 \\
\hline $\begin{array}{l}\text { Monday, } \\
\text { 2:00 PM }\end{array}$ & 28 & $62 \%$ & 11 & $24 \%$ & 3 & 3 & 3 & 7 & $22 \%$ & 26 & $58 \%$ & 4 & 0 & $9 \%$ & 45 \\
\hline $\begin{array}{l}\text { Monday, } \\
\text { 6:00 PM }\end{array}$ & 44 & $51 \%$ & 23 & $27 \%$ & 3 & 16 & 10 & 3 & $15 \%$ & 54 & $63 \%$ & 0 & 5 & $6 \%$ & 86 \\
\hline $\begin{array}{l}\text { Monday, } \\
\text { 10:00 PM } \\
\end{array}$ & 50 & $75 \%$ & 13 & $19 \%$ & 1 & 3 & 16 & 13 & $43 \%$ & 28 & $42 \%$ & 2 & 16 & $27 \%$ & 67 \\
\hline $\begin{array}{l}\text { Tuesday, } \\
\text { 2:00 PM }\end{array}$ & 29 & $85 \%$ & 3 & $9 \%$ & 0 & 2 & 7 & 5 & $35 \%$ & 25 & $74 \%$ & 2 & 0 & $6 \%$ & 34 \\
\hline $\begin{array}{l}\text { Tuesday, } \\
\text { 6:00 PM }\end{array}$ & 42 & $48 \%$ & 25 & $28 \%$ & 0 & 21 & 3 & 18 & $24 \%$ & 33 & $38 \%$ & 0 & 9 & $10 \%$ & 88 \\
\hline $\begin{array}{l}\text { Tuesday, } \\
\text { 10:00 PM } \\
\end{array}$ & 72 & $64 \%$ & 29 & $26 \%$ & 3 & 8 & 18 & 12 & $27 \%$ & 37 & $33 \%$ & 8 & 13 & $19 \%$ & 112 \\
\hline $\begin{array}{l}\text { Wednesday, } \\
\text { 2:00 PM }\end{array}$ & 27 & $57 \%$ & 13 & $28 \%$ & 3 & 4 & 6 & 11 & $36 \%$ & 40 & $85 \%$ & 0 & 0 & $0 \%$ & 47 \\
\hline $\begin{array}{l}\text { Wednesday, } \\
\text { 6:00 PM }\end{array}$ & 44 & $70 \%$ & 14 & $22 \%$ & 1 & 4 & 12 & 6 & $29 \%$ & 32 & $51 \%$ & 8 & 3 & $17 \%$ & 63 \\
\hline $\begin{array}{l}\text { Wednesday, } \\
\text { 10:00 PM }\end{array}$ & 34 & $63 \%$ & 8 & $15 \%$ & 2 & 10 & 6 & 12 & $33 \%$ & 23 & $43 \%$ & 4 & 7 & $20 \%$ & 54 \\
\hline $\begin{array}{l}\text { Thursday, } \\
\text { 2:00 PM }\end{array}$ & 15 & $63 \%$ & 9 & $38 \%$ & 0 & 0 & 3 & 3 & $25 \%$ & 12 & $50 \%$ & 4 & 0 & $17 \%$ & 24 \\
\hline $\begin{array}{l}\text { Thursday, } \\
\text { 6:00 PM } \\
\end{array}$ & 22 & $58 \%$ & 8 & $21 \%$ & 2 & 6 & 1 & 5 & $16 \%$ & 32 & $84 \%$ & 2 & 4 & $16 \%$ & 38 \\
\hline \begin{tabular}{|l|} 
Thursday, \\
10:00 PM \\
\end{tabular} & 15 & $45 \%$ & 17 & $52 \%$ & 1 & 0 & 7 & 8 & $45 \%$ & 8 & $24 \%$ & 4 & 3 & $21 \%$ & 33 \\
\hline Totals & 545 & & 202 & & 23 & 83 & 142 & 123 & & 409 & & 58 & 97 & & 853 \\
\hline \begin{tabular}{|l}
$\begin{array}{l}\text { Overall } \\
\text { percentages }\end{array}$ \\
\end{tabular} & $64 \%$ & & $24 \%$ & & $3 \%$ & $10 \%$ & $17 \%$ & $14 \%$ & $31 \%$ & $48 \%$ & & $7 \%$ & $11 \%$ & $18 \%$ & \\
\hline
\end{tabular}

Table 1: Observation counts 
We observed a total of 853 activities on the second floor of the library during the 5 days of observation. The "Design Brainstorm Sessions" provided qualitative information on how people used the library and what changes they would like to see in order to make it more useful. In analyzing the maps, we found that students' designs encompassed similar themes: learning spaces, technology, comfort and resources/staff.

The "Activity Study" revealed that $64 \%$ of the total activity was academic. Furthermore, $48 \%$ of the users worked alone. We also observed students engaged in more than one activity at a time. For example, students would be working on their laptop alongside a desktop and using their cellphone. In the "Design Brainstorm Sessions," students spoke about the desire to work alone on the computers. One student commented that she felt "too close" to others when working on the computer and would prefer more privacy. Several students drew larger computer spaces on their maps where they had more space to do their work. The desire to work alone and the multiple activities observed in the "Activity Study," along with the student discussions of space implied that students needed more individual space to do their work in the library.

Many students in the "Design Brainstorm Sessions" thought some of the space on the main floor should be quiet study area and drew computers in that space. One student said that she found it distracting to work at the reference area computers because of the high noise level caused by groups of students congregating there. Another student explained that often she couldn't find space on the "quiet floors" and thus had to work on the main floor. The quiet study spaces in the designs were often partitioned off by walls to prevent noise and students also emphasized the need for quiet by writing "no cellphones" or "no talking" in the space on their maps. The design workshops reinforced our "Activity Study" which found that many students chose to work alone on the main floor of the library.

The "Activity Study" also revealed that at certain times during the day, users studied in pairs or groups rather than worked alone. For example, at the Sunday 6:00 pm observation we noticed that $45 \%$ studied in pairs or groups and only $26 \%$ worked alone during the same time period. We also observed more group activity at the 10:00 pm observations from Monday - Thursday than at other times during the day. The students' maps from the "Design Brainstorm Sessions" indicated a desire for more group areas on the floor. The current group areas are "high real estate" in the library, as one student put it, and those areas fill up quickly.

Students created group rooms on the floor providing designated areas for students to meet. Even though the library provides group study rooms on other floors, one student said those get taken quickly and get hot when you have a large group meeting. One map had group areas with movable cubicle walls which students could use to section off the space rather than having rooms with ceiling to floor walls. Both the "Activity Study" and "Design Brainstorm Sessions" revealed that students need more group space in our library.

In the "Activity Study" and "Design Brainstorm Sessions," we noticed that the late night lab, comprised of a computer lab, a classroom, a small group room and an open study area, was a highly used space. Our 2:00 pm observations from 
Monday - Thursday revealed that regularly scheduled classes primarily used the space with low individual activity, but at the 6:00 pm and 10:00 pm times, students, either individually or in groups, occupied it. Student discussion in the "Design Brainstorm Sessions" focused on this area of the library. Their designs indicated the need for the space to be bigger and to provide group as well as silent study space. In some of the designs, students circled the entire 2nd floor map and students wrote "make 24 hours."

Many students use laptops at our institution and we noticed an increase usage in the library which prompted our interest in learning more about laptop usage on the main floor. The "Activity Study" gave us the opportunity to count the laptop usage. Daily laptop activity varied but at times we saw that more than half of the total activity on the floor was on laptops. For example, laptop activity comprised $55 \%$ of the activity on Sunday at 10:00 pm. For the week, laptop activity accounted for an average of $31 \%$ of all activity. The "Design Brainstorm Sessions" concurred with our observations of laptop usage. One student said that many times students work in areas where there is an outlet but it is often not in a space conducive to doing work. She identified the café as one area where it is more convenient to use laptops since the tables can be easily moved and there are floor outlets. But because it is the café, the area gets busy and students get distracted. On the designs, students wrote "more outlets" showing a need throughout the main floor of the library. One student created a laptop area where students could plug in their computers to do their work.

As stated earlier, the main floor of Olin Library is an active place. The "Activity Study" indicated that our users do use the library for academic activity. The study also showed that recreation activity combined with cellphone or unengaged activity accounted for $36 \%$ of the total activity for the week. Thus, roughly onethird of our users were comfortable in the library doing activities that were not obviously academic. One comfort or recreational feature discussed in the "Design Brainstorm Sessions" was the café. Students drew a larger café in their designs and suggested more of a selection of food items. One student mentioned that the café didn't feel like a "café" but more like "an airport kiosk." Students indicated in their designs that the café should be more defined with walls. In addition, it should have longer hours of operation. Similarly, students also enjoyed the large comfy chairs provided on the main floor and according to our observations used them regularly. In the design sessions, students wrote "keep comfy chairs" on their maps and drew more of them especially in the café area.

With respect to staff and resources the "Design Brainstorm Sessions" provided an informative perspective. Currently, our vast print reference collection is shelved on the main floor. Students in the group who were familiar with these resources believed these materials should be moved to make more space for students. In addition, students expressed difficulty in finding help on the main floor. Their designs included signs indicating where students could ask for and receive help. Students liked the current location of the circulation desk near the entrance which they made evident in the discussions and in their designs. But, they relocated the reference desk from its current location along the wall and placed it closer to the entrance in order for it to be more visible. From the "Design Brainstorm 
Sessions," we learned that the library must make it easier for students to solicit help from librarians by making the reference desk more accessible.

\section{Conclusions and next steps}

At Olin Library, we aim to provide a welcoming environment to our community where they can utilize the space to their benefit. Our initial research has given us insight regarding the needs of the users on the main floor of the library. We expect to do follow up ethnographic research at our library and plan to conduct an "Activity Study" and "Design Brainstorm Sessions" on other floors of the library to learn more about how our patrons use those spaces. Students frequently spoke about the late night lab during the "Design Brainstorm Sessions" and the "Activity Study" which revealed that many students are in this space at 10:00 pm. We are unfamiliar with the activities of that space because neither librarians nor staff members monitor it from 12:00 am - 7:45 am when students use it. Future research will be conducted in this space in order for the library to create a better environment for users during the late night hours. We may recruit students to do the research as Milner Library at Illinois State University did for theirs (Hunter, 2011). We also would like to learn more about students who do not come to the library. Learning why they choose not to use the library space will provide insight into what changes we can make in order for it to serve their needs better. Using either quantitative or qualitative methods regarding our users will provide accurate data that will help us improve our library space.

Ethnographic research provides essential data and information about people, their daily lives, their likes and dislikes as well as their wishes for change. Academic libraries have utilized ethnographic studies to redesign a library space, a service, or develop a better understanding of the users at their institution. The results from both the "Activity Study" and the "Design Brainstorm Sessions" provided us with useful data that complemented each other. With the data we were able to contextualize or make "connections between bits of information gathered" developing similar themes regarding our users' needs and learning about their diverse needs (Bloomaert and Jie, 2010). They want to study alone but still need space to meet in groups. Users want to feel comfortable in that space and food, furniture and the opportunity to use the library for more than just academic activities all play a role in creating comfort. They utilize technology in the form of laptops, desktops, and cellphones and thus need the space to use them effectively. That space can be in the form of providing more outlets or a larger work area. Therefore, both qualitative and quantitative methods provided consistent results giving us a clearer picture of our users and their needs.

Each study provided different data regarding our library space and our users. The "Activity Study" gave us numerical counts of the different activities of our users. The "Design Brainstorm Sessions" provided students the opportunity to express their views on how they use the library space and designed. Both studies were valuable exercises where we learned about how our library space is utilized and what changes students would like to see in the space. The "Activity Study" gave us the opportunity to dedicate resources to collect raw data about our users' activities in the library which we could then calculate. The "Design Brainstorm Sessions" gave us a chance to learn directly from our students about how they use 
the library space. The studies educated us more about our users beyond anecdotes the librarians shared with one another and provided valid results that we could utilize in our space planning.

Libraries would certainly benefit from conducting ethnographic research utilizing either quantitative or qualitative methods. Due to staff or financial constraints, completing two studies may not be an option. But accomplishing either type of study would prove to be a useful exercise giving libraries an enhanced perspective on their users' space needs. A quantitative or qualitative study would provide the needed data and assurance to make essential changes to improve their patron's library experience.

\section{References}

Aurand, M. (n.d.) What is a Charette? URL:

http://www.andrew.cmu.edu/user/ma1f/ArchArch/Charette/what.html [accessed 3.6.11].

Bloomaert, J. and Dong J. (2010) Ethnographic fieldwork: a beginner's guide. Bristol, UK: Multilingual Matters.

Bourdieu, P., Passeron, J., and de Saint Martin, M. (1994) Academic discourse: linguistic misunderstanding and professional power. (Richard Teese, Trans.). Stanford, CA: Stanford University Press. (Original work published 1965).

Briden, J., Burns, V. and Marshall A. (2007) Knowing our students: undergraduates in context. ACRL 13th National Conference Proceedings, Baltimore, MD. URL:

http://www.ala.org/ala/mgrps/divs/acrl/events/national/baltimore/papers/184.pdf [accessed 23.4.11].

Bryant, J. (2009) What are students doing in our library? Ethnography as a method of exploring library user behavior. Library and Information research URL:

http://www.lirg.org.uk/lir/ojs/index.php/lir/article/viewDownloadInterstitial/95/15 1 [accessed 12.5.11].

Buchanan, E. (2000) Ethics, qualitative research, and ethnography in virtual space. Journal of Information Ethics, 9(2), 82-87.

Foster, N. and Gibbons, S. (eds.) (2007) Studying students: The undergraduate research project at the University of Rochester. Chicago: ACRL. URL: http://www.ala.org/ala/mgrps/divs/acrl/publications/digital/FosterGibbons_cmpd.pdf [accessed 23.4.11]

Hobbs, K. and Klare, D. (2010) User driven design: using ethnographic techniques to plan student study space. Technical Services Quarterly, 27(4), 347363.

Hunter, G and Ward, D. (2011) Students research the library: using student-led ethnographic research to examine the changing role of campus libraries. College \& Research Libraries News, 72(5), 264-268. 
LaFlamme, M. (2007) Towards a progressive discourse on community needs assessment: perspectives from collaborative and action research. Progressive Librarian [online]. URL: http://libr.org/plg/Braverman2007.pdf [accessed 23.4.11].

The Library Planning Task Force (2005) Final report for the Jesse Ball Dupont Library. URL: http://library.sewanee.edu/libplan/LPTF\%20Final\%20Draft\%20411.pdf [accessed 23.4.11].

Mariampolski, H. (2006) Ethnography for marketers: a guide to consumer immersion. Thousand Oaks, CA: Sage Publications.

University of Massachusetts, Amherst (2010). Learning commons assessment. URL: http://www.library.umass.edu/assessment/learningcommons.html [accessed 04.01.12].

\section{Open access and copyright}

Library and Information Research is an open access journal. A freely available copy of this paper may be downloaded from the journal's website: http://www.cilipjournals.org.uk/lir

Copyright and associated moral rights in works published in Library and Information Research are retained by the author(s) but this paper may be used freely, with proper attribution, in educational and other non-commercial settings. 